\author{
Monika KOWALSKA \\ ORCID: 0000-0002-3188-6946 \\ Uniwersytet Pedagogiczny im. KEN \\ w Krakowie
}

\title{
Wolontariat po studencku - inspiracja i zaangażowanie studentów pedagogiki specjalnej w działalność wolontariacką
}

\begin{abstract}
Volunteering on the student side - inspiration and participation of pedagogy students in voluntary activities

The article discusses the issue of student volunteering. The first part discusses the theoretical background of the problem in the literature of the subject: the definitions of volunteering, sources of motivation, legal issues and qualifications and competences to the concept of volunteer role. The next part presents and discusses the results of our own research focused on the forms of volunteering carried out by students of special pedagogy.
\end{abstract}

Keywords: student volunteering, volunteer, competence, motivation

Słowa kluczowe: wolontariat studencki, wolontariusz, kompetencje, motywacja

\section{Wprowadzenie}

Zagadnienie wolontariatu jest $\mathrm{w}$ ostatnich latach bardzo żywo dyskutowane w mediach, ale także staje się obszarem eksploracji badaczy, chcących ukazać różne aspekty działań społecznych. Wymienić można tu artykuły naukowe zawarte w publikacjach pod redakcją: M. Muchackiego, J. Machowskiej-Goc i B. Sufy (2020); E. Kulszy i B. Kosewskiej (2017); P. Grzybowskiego i N. Woderskiej (2014); A. M. Koli i K. Wasilewskiej-Ostrowskiej (2012); M. DanielakChomać, B. Dobrowolskiej i A. Rogulskiej, (2010), a także monografie autorskie, traktujące o wybranym aspekcie działalności wolontaryjnej: M. Barańskiej (2016); P. Hanygi-Janczak (2013); D. Buttlera (2011); A. Kanios (2010). Podjęte kierunki badawcze prawdopodobnie związane są ze wzrostem zainteresowania człowiekiem w trudnej sytuacji - chorym, cierpiącym, biednym. Pojawił 
się także obywatelski sens odpowiedzialności i uczestnictwa w życiu społecznym. Zauważalna jest e tendencja do "traktowania wolontariatu jako drogi zdobywania doświadczeń, które mogą ułatwić start w dorosłe życie”, co kreuje potrzebę dostosowania merytorycznego i organizacyjnego instytucji zajmujących się wolontariatem (Jaronowska, 2017, s. 19). Zmieniająca się rzeczywistość powoduje także potrzebę uelastyczniania form niesienia pomocy oraz uaktualnienia listy jej adresatów. Wszystkie te aspekty sprawiają, że wolontariat coraz częściej staje się istotnym elementem niemalże każdego współczesnego społeczeństwa (Gawroński, 1999, s. 26).

\section{Wolontariat w świetle literatury przedmiotu}

Choć od początku życia ludzkości funkcjonowały w społeczeństwach inicjatywy o charakterze charytatywnym i filantropijnym, nie były one uregulowane prawnie i nie nosiły nazwy wolontariatu. Genezy pojęcia „wolontariat” należy upatrywać w łacińskim słowie voluntas, oznaczającym nieodpłatne, świadome i dobrowolne działanie na rzecz innych osób, społeczności czy organizacji, odbywające się stale bądź okazjonalnie (Kanios, 2010, s. 50). Termin „wolontariat" krystalizował się i zyskiwał na znaczeniu w miarę rozwoju licznych instytucji pozarządowych, kształtujących świadomość społeczną. Bardzo istotnym dokumentem prawnym regulującym kwestie wolontariatu w Polsce jest Ustawa o działalności pożytku publicznego i o wolontariacie z 24 kwietnia 2003 r., w myśl której wolontariat to aktywność odpowiadająca świadczeniu pracy. W terminologii prawniczej i ekonomicznej wolontariuszem jest każdy, kto ochotniczo i bez wynagrodzenia wykonuje świadczenia na zasadach określonych w ustawie ${ }^{1}$. W Polsce pojęcie wolontariatu zaczęło kształtować się po 1989 r., ale w tradycji wolontariat stawał się już wcześniej sposobnością do nabywania kompetencji zawodowej (Kanios, 2010, s. 49). W 1993 r. powstało Centrum Wolontariatu (od 2006 r. jest to Stowarzyszenie), którego celem jest promocja idei wolontariatu oraz pośrednictwo między wolontariuszami a organizacjami deklarującymi chęć przyjęcia ich w swoje szeregi (Michaluk, 2013, s. 13). Analizy CBOS-u z 2019 r. ukazują rosnący trend związany z zaangażowaniem Polaków w pracę społeczną: $18 \%$ badanych w ciągu 12 miesięcy poprzedzających badanie poświęciło swój wolny czas na pracę zarówno na rzecz własnej społeczności, jak i organizacji obywatelskich; $24,5 \%$, ankietowanych świadczyło pracę $\mathrm{w}$ organizacjach obywatelskich, zaś $8 \%$ respondentów podejmowało działania na rzecz środowiska lokalnego ${ }^{2}$. Najnowsze zestawienie GUS z 2016

\footnotetext{
${ }^{1}$ http://isap.sejm.gov.pl/DetailsServlet?id=WDU20160000239 (dostęp 30 III 2019).

2 https://www.cbos.pl/SPISKOM.POL/2020/K_037_20.PDF (dostęp 30 X 2021).
} 
r. wskazuje, że najliczniejszą grupą osób udzielających się w wolontariacie stanowili ludzie młodzi w wieku od 15 do 24 lat, a więc osoby uczące się bądź studiujące. Drugą pod względem liczebności grupą byli wolontariusze w wieku od 35 do 44 lat, mający ugruntowaną pozycję socjoekonomiczną ${ }^{3}$.

D. H. Smith, uwzględniając wytyczne Międzynarodowej Organizacji Pracy, definiuje wolontariat, jako aktywność, która nie jest zdeterminowana przez sferę biologiczną (np. sen, jedzenie, odpoczynek), ekonomiczną (np. praca zarobkowa, prace domowe), polityczną, ani społeczną (płacenie podatków, ubieranie się przed pojawieniem się w miejscu publicznym) (za: D. Buttler, 2011, s. 13). S. Gawroński (1999, s. 224) jako cechy dystynktywne dla działalności wolontaryjnej wskazuje: wysoki poziom świadomości i motywacji w zakresie udzielania bezinteresownej pomocy, wykonywanie jej konsekwentnie, w sposób ciągły i systematyczny. B. Dobrowolska (2010, s. 68-69) zaznacza, że ankietowani w jej badaniach za kluczowe dla wolontariusza cechy uznali: odpowiedzialność, satysfakcję z niesienia pomocy oraz miłość do ludzi.

Świadczona pomoc może przybierać różne formy, w zależności od potrzeb beneficjentów. Wyróżniając rodzaje wolontariatu, należy zwrócić uwagę na czas jego trwania. W związku z tym kryterium wyróżnia się: wolontariat stały (długo- i krótkoterminowy), jednorazowy, a także wolontariat okolicznościowy, tzw. akcyjny (Bejma, 2012, s. 43). Pierwszy typ wymaga umowy formalnej i realizowany jest w sposób ciągły, w przeciwieństwie do drugiego typu, w którym wolontariat realizowany jest jednorazowo jako pomoc osobom w potrzebie. Inna typologia zwraca uwagę na zasięg prowadzonych działań. W tym kontekście wyróżnia się wolontariat: lokalny, krajowy oraz zagraniczny (Golicz, 2015, s. 10). Ten ostatni oparty jest na programach, takich jak np. rok socjalny czy workcamp, w ramach którego wolontariusz pracuje w zagranicznych placówkach socjalnych, otrzymując za to kieszonkowe oraz zakwaterowanie. Szczególną formą wolontariatu zagranicznego są misje w celu poprawy jakości życia społeczności z terenów wymagających wsparcia w różnym zakresie: pomocy medycznej, edukacji, programów profilaktycznych przeciwdziałających patologiom i łagodzenia skutków klęsk i epidemii itp. Ważne miejsce w klasyfikacji zajmuje wolontariat pracowniczy, w ramach którego A. Musiała wyróżnia wolontariat obligatoryjny (dobrowolnie świadczona praca, bez gratyfikacji pieniężnej, której wykonanie warunkuje zdobycie zawodu) oraz fakultatywny (podejmowany w celu zdobycia doświadczenia bądź zatrudnienia w instytucjach, w których pracuje się woluntarystycznie (za: Kanios, 2010, s. 53). J. Golicz (2015, s. 16) dokonała systematyzacji nowatorskich form wolontariatu, którymi są: streetworking (praca terenowa o charakterze prewencyjno-po-

${ }^{3}$ https://stat.gov.pl/files/gfx/portalinformacyiny/pl/defaultaktualnosci/5491/1/3/1/wolontariat_ w_2016.pdf 
mocowym $\mathrm{z}$ dziećmi oraz młodzieżą $\mathrm{w}$ ich naturalnym środowisku) oraz partyworking (praca o charakterze terenowym podczas imprez masowych). Z kolei M. Muchacki (2020, s. 80) wskazuje liczne korzyści płynące z zaangażowania $\mathrm{w}$ wirtualny wolontariat, w którym: „Cyfrowi wolontariusze korzystają $\mathrm{z}$ technologii, $\mathrm{w}$ tym $\mathrm{z}$ mediów społecznościowych, aby pomóc osobom $\mathrm{w}$ różnych trudnych sytuacjach życiowych".

Działania w wolontariacie mogą mieć różne modele. W literaturze wyróżnia się modele:

— spontanicznej życzliwości - realizowany w środowisku rodzinnym, sąsiedzkim, wynikający $\mathrm{z}$ tradycji i norm etyczno-moralnych;

- pomocy zinstytucjonalizowanej — wsparcie przekazywane jest w środowisku lokalnym przez udzielanie konkretnej, doraźnej pomocy jakiejś grupie osób, która w danym momencie nie może uporać się z problemami takimi, jak: bieda, bezrobocie, konflikty społeczne, wykluczenie;

- o charakterze społeczno-biurokratycznym - działalność wolontariacka podejmowana jest pod kontrolą i z udziałem państwa, na podstawie umowy. Tego typu działalność na rzecz innych odbywa się z wykorzystaniem subwencji budżetowej;

- instytucjonalny (zetatyzowany) - przybiera formę działań sformalizowanych i zinstytucjonalizowanych, podejmowanych systematycznie przez osoby przygotowane do tego merytorycznie (Golicz, 2015, s. 8-10).

Obszernie aspekty prawne, określające funkcjonowanie wolontariuszy w Polsce wraz z przykładowymi wzorami pism oraz wykazem miejsc, w których wolontariusze otrzymają różnego rodzaju wsparcie, omawia w swojej publikacji M. Falej (2011). Autorka stworzyła opracowanie traktujące o kwestiach prawnych pracy wolontariackiej, nawiązując do obecnie wykorzystywanych dokumentów urzędowych. Skarbnicą wiedzy jest także strona internetowa Ogólnopolskiej Sieci Centrów Wolontariatu ${ }^{4}$, na której zakładkach w przejrzysty sposób przekazane są wiadomości dotyczące: sposobów stawania się wolontariuszem, rozwijania się przez wolontariat, historii wolontariatu, strategii współpracy instytucji z wolontariuszami, a przede wszystkim strona zawiera wykaz instytucji, które potrzebują wsparcia wolontariuszy. Na stronie Centrum Wolontariatu nie zabrakło także publikacji badań i przeglądu literatury dotyczącej omawianej tematyki.

P. Jordan i M. Ochman (1997, s. 5) zakładają, że „[w]olontariuszem może być każdy, w każdej dziedzinie życia społecznego, wszędzie tam, gdzie taka pomoc jest potrzebna, ale nie każdy wolontariusz jest odpowiedni dla każdego rodzaju pracy". Powstaje zatem pytanie, jakimi kompetencjami powinien odznaczać się wolontariusz. Jest to jednak pole badań jeszcze słabo rozpoznane

\footnotetext{
${ }^{4}$ http://wolontariat.org.pl/
} 
(Kanios, 2010, s. 42). Być może dlatego, że kompetencje nie są cechami stały$\mathrm{mi}$, ponieważ zmieniają się $\mathrm{w}$ toku życia człowieka na podstawie zdobywanej wiedzy i doświadczeń. W myśl słów P. Jordana i M. Ochman praca wolontariusza jest aktywnością niejednorodną, często interdyscyplinarną, kompetencje zatem zależą od specyfiki środowiska, w którym realizowane są działania wolontariuszy. Ponadto pomiar kompetencji jest złożonym procesem. Zestaw narzędzi do oceny kompetencji wolontariuszy stanowi rezultat projektu „IMPROVE - IMPact Of VoluntEering on personal and professional Growth", realizowanego w ramach programu GRUNDTVIG. Celem twórców zestawu było dostosowanie narzędzi służących do oceny umiejętności i kompetencji stosowanych w poradnictwie zawodowym do potrzeb działalności w wolontariacie. Zaproponowane narzędzia służą do samooceny kandydatów na wolontariuszy, a także pozwalają na planowanie działania przez tworzenie planu rozwoju ${ }^{5}$. W literaturze przedmiotu na temat kompetencji społecznych wolontariuszy wypowiadała się A. Kanios (2010, s. 85-159), zaś kolei B. Kromolnicka (2000, s. 108-112) skupiła się na kompetencjach opiekuńczych do pracy w wolontariacie hospicyjnym.

Omawiając problematykę wolontariatu, należy zwrócić także uwagę na kwestię kwalifikacji do wykonywanych zadań. Jest ona istotna, ponieważ wolontariusze realizują swoją pracę w różnych formach, począwszy od kontaktu $\mathrm{z}$ drugim człowiekiem, skończywszy na pracach biurowych, administracyjnych czy technicznych. Niektóre $\mathrm{z}$ aktywności powierzanych wolontariuszom wymagają od nich ustalonych dyrektywami prawnymi kwalifikacji bądź predyspozycji osobowościowych, doświadczenia i sprawności w działaniu na danym obszarze.

Wśród respondentów E. Jurczak (2011, s. 142-144) najczęstszymi motywami udziału w wolontariacie były: pragnienie zaspokajania potrzeb i pomoc innym; chęć zapoznania się z ciekawymi osobami; poszerzenie wiedzy, umiejętności i doświadczenia w danej dziedzinie; potrzeba uznania. Respondenci rzadziej wymieniali przymusowe działanie i chęć zrewidowania własnych, podobnych doświadczeń życiowych. Z kolei według analiz J. Dąbrowskiej i K. Wygnańskiego (2002, s. 54-61), u podstaw udziału w wolontariacie leżą głównie motywy religijne i moralne. P. Hanyga-Janczak (2013) podaje, że studenci studiów stacjonarnych jako bodźce do działań o charakterze wolonatriackim podawali $\mathrm{w}$ ankietach kolejno: misję niesienia pomocy potrzebującym, sprawdzenie umiejętności zdobytych podczas studiów w praktyce zawodowej czy też wypełnienie wolnego czasu. A. Matuszewska (2010) w wywiadach z młodymi ludźmi wskazuje na edukacyjny aspekt udziału w wolontariacie, szczególnie odzwierciedlający się $\mathrm{w}$ sferze intrapersonalnej: poznaniu siebie, kreowaniu własnej

${ }^{5}$ http://fundacja-umbrella.org.pl/portfolios/improve-impact-of-volunteering-on-personal-andprofessional-growth/ (dostęp 20 XI 2021). 
tożsamości wynikającej z wkraczania w kolejny etap życia bądź uświadomieniu sobie, że wolontariusz nie jest gotowy na kolejne życiowe kroki. Wolontariat jest szansą rozwoju wiedzy i umiejętności, co może przyczynić się do wyznaczenie celów i wyboru drogi zawodowej ludzi młodych (Targowska, 2017, s. 33 -46). Kolejno $86 \%$ studentów biorących udział $\mathrm{w}$ badaniach ankietowych M. Brańskiej (2016, s. 196) potwierdziło, że wolontariat wspiera proces planowania kariery zawodowej, gdyż „pozwala skonfrontować wyobrażenia dotyczące zawodu z rzeczywistością" oraz „daje możliwość zweryfikowania lub potwierdzenia podjętych dotychczas wyborów edukacyjno-zawodowych". A. Szkolak-Stępień i E. Ir (2020) wskazują na liczne korzyści płynące z udziału w wolontariacie dla studentów pedagogiki przedszkolnej i wczesnoszkolnej, zaznaczając jednak, że brak jednoznacznych analiz dotyczących znaczenia praktyk wolontariackich dla rozwoju zawodowo-osobowościowego kandydatów na nauczycieli małego dziecka.

Formą pomocy drugiemu człowiekowi może być właśnie edukacja i zachęcanie do rozwijania własnych pasji i marzeń. To jedno z zadań przyświecających programowi „Projektor - wolontariat studencki”6, realizowanemu przez studentów, pracowników naukowych, ekspertów i innowatorów edukacyjnych w szkołach mieszczących się w małych miejscowościach w Polsce (Barwicka, Andrzejak, 2012, s. 175-181).

Często zapominamy, jak duże korzyści społeczne niesie zaangażowanie w wolontariat. Aktywność wolontaryjna pozwala m.in. na nabywanie nowych kompetencji zawodowych i społecznych przez ludzi młodych i bez doświadczenia. Aktywizuje i zapobiega marginalizacji społecznej po utracie zatrudnienia bądź przejściu na emeryturę, stwarza też przestrzeń dla zaangażowania się ludzi wykluczonych $z$ uwagi na niepełnosprawność. Korzyści mogą być zatem trójstronne - wolontariusz, osoba, której udzielane jest wsparcie, a czasem i placówka gdzie realizowane są działania pomocowe (Roguska 2010, s. 39).

W dalszej części pracy zaprezentowane zostaną badania własne dotyczące podejmowanych przez studentów pedagogiki specjalnej aktów wolontariatu.

\section{Badania własne}

Zasadniczym celem podjętych badań było ustalenie form aktywności wolontaryjnej studentów pedagogiki specjalnej. Przedstawione tło teoretyczne badań składnia do odpowiedzi na następujące pytania:

- Jak studenci pedagogiki specjalnej definiują pojęcie wolontariatu?

- Jakiego rodzaju wolontariat podejmują studenci pedagogiki specjalnej?

${ }^{6}$ https://projektor.org.pl/o-nas/ 
- Jaka jest motywacja studentów pedagogiki specjalnej do podejmowania aktywności wolontaryjnej?

- Jakie kompetencje powinna mieć osoba pełniąca rolę wolontariusza $\mathrm{w}$ opinii badanych? denci?

- Jakie pozytywne, a jakie negatywne strony wolontariatu zauważają stu-

Badania przeprowadzono metodą sondażu diagnostycznego, w ramach którego wykorzystano technikę ankiety. Grupę badawczą stanowiły 64 studentki III roku pedagogiki specjalnej. Wszystkie badane osoby były kobietami. Kwestionariusz ankiety skierowany był zarówno do studentów, którzy podejmowali wolontariat, jak i do tych, którzy nie byli zaangażowani w taką działalność. Wśród badanych aż 60 osób kiedykolwiek podejmowało aktywność wolontariacką. Respondentki deklarowały głównie uczestnictwo w wolontariacie na terenie miast, a tylko $10 \%$ badanych osób podejmowało wolontariat na terenie wsi. Żadna ze studentek nie uczestniczyła $\mathrm{w}$ wolontariacie zagranicznym.

Kolejne pytanie dotyczyło stażu pracy w wolontariacie. Najwięcej respondentek bierze udział $\mathrm{w}$ wolontariacie od 2-3 lat $-28 \%$, od roku w wolontariacie uczestniczy $27 \%$, a powyżej 5 lat w tego typu działania angażuje się $15 \%$ ankietowanych. Blisko jedna czwarta respondentek wykazała, że jednorazowo wchodziła w rolę wolontariusza. Zestawienie liczbowe prezentuje tabela 1 .

Tabela 1. Staż pracy w wolontariacie

\begin{tabular}{|c|c|c|}
\hline Staż pracy wolontaryinej & Liczba odpowiedzi & [\%] \\
\hline Jednorazowa pomoc & 14 & 23 \\
\hline 1 rok & 16 & 27 \\
\hline 2-3 lata & 17 & 28 \\
\hline 4-5 lat & 4 & 7 \\
\hline Powyżej 5 lat & 9 & 15 \\
\hline Razem: & 60 & 100 \\
\hline
\end{tabular}

Źródło: opracowanie własne na podstawie wyników badań.

Badanych studentów proszono o stworzenie definicji wolontariatu. Badane najczęściej podkreślały fakt bezinteresowności i pomocy potrzebującym. Wśród podanych definicji pojawiły się: „Pomoc innym z własnej woli, za którą nie pobiera się zapłaty, która daje dużo satysfakcji ”; „[...] dajesz, ale jeszcze więcej zyskujesz, spróbuj, a będziesz szczęśliwszym człowiekiem”, a także „to dobrze spędzony wspólnie czas, dający pozytywne aspekty obu stronom ". Kryteria definicyjne najczęściej pojawiające się $\mathrm{w}$ odpowiedziach zestawiono w tabeli 2 . 
Tabela 2. Kryteria definicyjne wolontariatu w wypowiedziach studentów

\begin{tabular}{|l|c|}
\hline Kryteria definicyjne wolontariatu & Liczba odpowiedzi $^{\star}$ \\
\hline Pomoc innym & 38 \\
\hline Bezinteresowność & 35 \\
\hline Działanie dobrowolne & 19 \\
\hline Bezpłatna pomoc & 12 \\
\hline Działanie przynoszące satysfakcje & 9 \\
\hline Pomoc zwierzętom & 7 \\
\hline Zdobywanie doświadczenia, wiedzy & 6 \\
\hline Produktywne spędzanie czasu & 5 \\
\hline
\end{tabular}

* Ze względu na złożoność wypowiedzi respondentów liczba odpowiedzi nie jest równa 60 . Źródło: Opracowanie własne na podstawie badań własnych.

Inna istotną kwestią jest motywacja do podejmowania działalności na rzecz innych. Na podstawie opracowanej przez D. Buttlera (2011, s. 12) typologii motywacji wolontariuszy najwięcej osób deklaruje, że motywacją są dla nich wyznawane wartości. Kolejno badane określiły, że kierują się w podejmowanych działaniach wolontariackich karierą: chęcią zdobycia doświadczenia czy pragnieniem uzupełnienia wykształcenia. Dla części badanych udział w wolontariacie jest spełnieniem marzeń. Prezentowana typologia oraz odpowiedzi z kwestionariuszy zostały ujęte w tabeli 3.

Studentki pedagogiki specjalnej podejmują różne rodzaje aktywności w ramach wolontariatu. Ponad połowa badanych (53\%) deklaruje ze względu na zainteresowanie zawodowe pomoc osobom niepełnosprawnym. 21\% ankietowanych studentek czynnie opiekuje się dziećmi podczas kolonii, zimowisk, bądź w świetlicach, organizując im czas wolny bądź pomagając przy odrabianiu lekcji. Respondentki podejmują także aktywność w zakresie kwestowania (13\% ankietowanych), zbiórki darów dla potrzebujących, wykonują prace biurowe w zakresie zbieranie podpisów, ankietowania, organizacji imprez plenerowych Prócz aktywności w zakresie pomocy ludziom kilka ankietowanych studentek deklaruje udział $\mathrm{w}$ wolontariacie na rzecz zwierząt.

Wśród kompetencji, którymi odznacza się wolontariusz, studentki zauważają, że powinien on mieć takie cechy, które z punktu widzenia interakcji społecznych mogą wspomagać realizację wyznawanych prospołecznych wartości. $\mathrm{Z}$ przeprowadzonych badań wynika, że wolontariuszy powinny charakteryzować: tolerancja, bezinteresowność, komunikatywność, otwartość, a także cierpliwość i odpowiedzialność. W zakresie kwalifikacji do podjęcia wolontariatu ponad połowa studentek kwitowała najczęściej tę kwestię hasłem „nie trzeba 
Tabela 3. Motywacje do podejmowanych działań wolontariackich

\begin{tabular}{|c|c|c|c|}
\hline $\begin{array}{l}\text { Funkcja } \\
\text { psychologiczna }\end{array}$ & $\begin{array}{c}\text { Zestawienie } \\
\text { liczby odpowiedzi }\end{array}$ & $\begin{array}{l}\text { Motywacje do podejmowanych } \\
\text { działań wolontaryjnych }\end{array}$ & $\begin{array}{l}\text { Liczba odpowiedzi } \\
\text { w poszczególnych } \\
\text { podskalach }{ }^{\star}\end{array}$ \\
\hline \multirow[t]{2}{*}{ Wartości } & \multirow[t]{2}{*}{29} & Chęć niesienia pomocy & 27 \\
\hline & & Miłość do zwierząt & 5 \\
\hline \multirow[t]{4}{*}{ Kariery } & \multirow[t]{4}{*}{28} & Możliwość kariery & 4 \\
\hline & & Uzupełnienie wykształcenia & 18 \\
\hline & & Zdobycie doświadczenia & 4 \\
\hline & & Uzyskanie zaświadczenia & 2 \\
\hline \multirow[t]{2}{*}{ Zrozumienia } & \multirow[t]{2}{*}{20} & $\begin{array}{l}\text { Doskonalenie warsztatu pracy, } \\
\text { wykorzystanie umiejętności } \\
\text { w praktyce }\end{array}$ & 15 \\
\hline & & Ciekawość & 5 \\
\hline \multirow[t]{3}{*}{ Wzmocnienia } & \multirow[t]{3}{*}{18} & $\begin{array}{l}\text { Poczucie przydatności, czuję się } \\
\text { potrzebna }\end{array}$ & 5 \\
\hline & & $\begin{array}{l}\text { Produktywne wykorzystanie czasu } \\
\text { wolnego }\end{array}$ & 3 \\
\hline & & Spełnienie marzeń & 10 \\
\hline \multirow[t]{3}{*}{ Społeczna } & \multirow[t]{3}{*}{12} & Światopogląd, ideologia życiowa & 2 \\
\hline & & $\begin{array}{l}\text { Autorytety, osoby znaczące były } \\
\text { motywacją }\end{array}$ & 8 \\
\hline & & Tradycje rodzinne & 2 \\
\hline Ochronna & 2 & $\begin{array}{l}\text { Poszukiwanie własnej drogi, kiedy } \\
\text { byłam w trudnej sytuacji }\end{array}$ & 2 \\
\hline Wzajemności & 3 & $\begin{array}{l}\text { Odwzajemnienie otrzymanej } \\
\text { pomocy }\end{array}$ & 3 \\
\hline \multirow[t]{2}{*}{$\begin{array}{l}\text { Społecznej } \\
\text { interakcji }\end{array}$} & \multirow[t]{2}{*}{9} & $\begin{array}{l}\text { Nawiązanie nowych kontaktów } \\
\text { (z osobami starszymi, z osobami } \\
\text { z doświadczeniem, poznani osób } \\
\text { wpływowych, przyjaciół) }\end{array}$ & 7 \\
\hline & & Wspólna zabawa & 2 \\
\hline
\end{tabular}

^ Ze względu na złożoność wypowiedzi respondentów, liczba odpowiedzi nie jest równa 60 . Źródło: Opracowanie własne na podstawie badań własnych i literatury (Buttler, 2011, s. 12) 
mieć kwalifikacji, ale dobre serce/dobre chęci”. Wśród wymienianych kwalifikacji wolontariusza studentki zauważają potrzebę wyposażenia wolontariusza w kwalifikacje społeczne: bezinteresowność (11 badanych), empatię (11 studentek), otwartość (9 respondentów) czy odpowiedzialność w podejmowanych działaniach (5 osób). Respondentki wśród kwalifikacji zaznaczają także: kurs pierwszej pomocy (8 osób), kurs animatora (7 badanych), a także podstawową wiedzę z dziedziny, której dotyczy wolontariat (5 osób), np. - w odniesieniu do pedagogiki specjalnej - jakimi trudnościami, potrzebami, ograniczeniami charakteryzują się osoby z danym typem niepełnosprawności.

Każda podejmowana aktywność wiąże się z pozytywnymi oraz negatywnymi stronami. Studentki zostały poproszone o wymienienie jednych i drugich. Wśród korzyści, które wolontariusze czerpią z wolontariatu, najczęściej badane wyodrębniły zdobyte doświadczenie, a także wiedzę specjalistyczną na temat funkcjonowania grup i osób w poszczególnych grupach społecznych (35 badanych studentek). W drugiej kolejności 29 respondentek podkreśla jako zaletę wolontariatu zdobywanie umiejętności związanych z komunikacją społeczną (nauka organizacji, poznanie nowych osób, integracja środowisk, rozpowszechnienie pomocy), a 35 - budowanie własnej osobowości (rozwijanie empatii, otwarcie na innych, satysfakcja, spełnienie, bycie potrzebnym). Wśród odpowiedzi badane zwracają uwagę na nabyte dzięki tego typu działalności umiejętności biurowe i techniczne.

Wśród negatywnych stron wolontariatu studentki wskazują najczęściej brak doceniania ich pracy (10 respondentek), poświęcanie czasu, przez co czasem zaniedbują obowiązki domowe, naukowe czy przyjacielskie (6 badanych). Inne osoby deklarują, iż często mają za mało czasu, by móc w pełni zaangażować się w działalność na rzecz innych (5 respondentek) bądź nie są w stanie podjąć działalności wolontaryjnej z powodów finansowych (5 studentek). Często studenci nie działają non profit $\mathrm{z}$ powodu przymusu podjęcia pracy zarobkowej podyktowanego koniecznością samodzielnego utrzymania się. Negatywnym zjawiskiem charakteryzującym wolontariat jest także nadmierna biurokratyzacja, na którą wskazują 3 badane. Znaczna część respondentek (23 osoby) nie zauważa w ogóle negatywnych stron podejmowania działalności wolontaryjnej.

\section{Podsumowanie i wnioski}

Przeprowadzona analiza, której przedmiotem jest źródło informacji na temat aktywności na rzecz społeczeństwa podejmowanej przez studentki pedagogiki specjalnej, pokazuje, że działalność wolontaryjna studentek stoi na bardzo wysokim poziomie. Najczęściej udzielana przez nie pomoc społeczna mieści się $\mathrm{w}$ ramach powszechnie rozumianego pojęcia wolontariatu, czyli dobrowolnej, 
bezpłatnej, świadomej pracy na rzecz innych lub całego społeczeństwa, wykraczającej poza związki rodzinne i przyjacielskie. W najwyższym stopniu studentki angażują się w wolontariat zinstytucjonalizowany, pomagając osobom niepełnosprawnym, chorym oraz podopiecznym domów dziecka i uczęszczającym do świetlic środowiskowych. Warte uwagi stają się także motywacje do podejmowania wolontariatu. Respondentki przeważnie uznają, że podejmowanie działalności wolontaryjnej podyktowane jest wyznawanym przez nich systemem wartości, a szczególności kierowaniem się chęcią bezinteresownej pomocy innym. Innym znaczącym czynnikiem staje się kwestia doskonalenia zawodowego: zdobycie nowych umiejętności, wiadomości czy wykorzystanie już posiadanych w praktyce.

Badania potwierdziły, iż najważniejszymi kompetencjami, którymi powinien odznaczać się wolontariusz, są kompetencje społeczne. Według ponad połowy badanych, aby podjąć działalność na rzecz innych, nie trzeba legitymować się szczególnymi kwalifikacjami, a trzeba jedynie mieć dobre serce i dobrą wolę. Respondentki wymieniały tylko kwalifikacje ponadzawodowe, potrzebne w każdej działalności podjętej we współpracy z drugim człowiekiem, czyli np. otwartość czy komunikatywność. Najwięcej satysfakcji z podejmowanych działań przynoszą zdobyte doświadczenia, a także specjalistyczna wiedza na temat funkcjonowania grup i osób w miejscach, w których studentki podejmują działalność wolontaryjną. W drugiej kolejności badane jako korzyści płynące $\mathrm{z}$ udziału w wolontariacie wymieniły umiejętności z zakresu komunikacji społecznej. Jak wskazują badane, będąc wolontariuszem, przeżywa się wiele doniosłych chwil, a także w atrakcyjny i twórczy sposób spędza czas oraz zawiązuje nowe przyjaźnie. Przez wolontariat można uczestniczyć w ciekawych przedsięwzięciach i spełniać swoje marzenia.

Za czynniki demotywujące badane uznały niedocenianie ich pracy, ale także brak gratyfikacji. Badania wykazały także, że część respondentek nie dostrzega negatywnych stron wolontariatu.

Wolontariat, choć ma wiele aspektów, zawsze wiąże się z pragnieniem bezinteresownego bycia dla innych i dzielenia się tym, co ma się najlepszego. Obecnie $\mathrm{z}$ wolontariatem spotykamy się właściwie w każdym miejscu: $\mathrm{w}$ szkole, w pracy, na ulicy. Wolontariusze pojawiają się wszędzie tam, gdzie to konieczne. Gdyby nie oni, w wielu przypadkach instytucje publiczne nie byłyby w stanie wspierać wszystkich potrzebujących. Podsumowaniem rozważań na temat wolontariatu niech staną się słowa św. Jana Pawła II, który powiedział: „Człowiek jest wielki nie przez to, co, posiada, lecz przez to, kim jest; nie przez to, co ma, lecz przez to, czym dzieli się z innymi”. 


\section{Bibliografia}

Barańska, M. (2016). Wolontariat w planowaniu kariery zawodowej studentów. Poznań: Wyd. Naukowe UAM.

Barwicka, A., Andrzejak, M. (2012). Program „Projektor — wolontariat studencki” jako forma aktywności spotecznej i lokalnej. W: A. M. Kola, K. M. Wasilewska-Ostrowska (red.), Wolontariat szansa rozwoju społecznego. Rekomendacje dla pracy socjalnej. Toruń: Wyd. Edukacyjne „Akapit”, s. 175-181.

Braun, K. (2012). Wolontariat, mtodzież, wychowanie. Lublin: Wyd. KUL.

Bejma, A. (2012). Rola wolontariatu w spoteczeństwie obywatelskim. W: A.M. Kola, K M. Wasilewska-Ostrowska (red.), Wolontariat szansa rozwoju spotecznego. Rekomendacje dla pracy socjalnej. Toruń: Wyd. Edukacyjne „Akapit”, s. 27-45.

Buttler, D. (2011). Pozycja wolontariuszy na rynku pracy. Poznań: Wyd. UE.

Dąbrowska, J., Wygański J. (2003). Magia liczb. W: M. Maciuła (red.), Barwy wolontariatu. Warszawa: Biuro Obsługi Ruchu Inicjatyw Społecznych, s. 54-61.

Dobrowolska, B. (2010). Wolontariat i postawy altruistyczne w opinii społecznej. Studenci wobec wolontariatu — analiza badań. W: M. Danielak-Chomać, B. Dobrowolska, A. Rogulska (red.), Wolontariat w teorii i praktyce. Siedlce: Fundacja na Rzecz Dzieci i Młodzieży „Szansa”, s. 59-79.

Falej, M. (oprac.). (2011). ABC wolontariatu. Olsztyn: FIKA.

Gawroński, S. (1999). Ochotnicy miłości bliźniego. Przewodnik po wolontariacie. Przeł. B. Topolska. Warszawa: Biblioteka „Więzi”.

Golicz, J. (2015). Poradnik dla wolontariuszy. Ruda Śląska: Stowarzyszenie na Rzecz Dzieci i Młodzieży „Przystanek”.

Hanyga-Janczak, P. (2013). Praca zarobkowa $i$ wolontariat w czasie wolnym studentów studiów stacjonarnych. Próba eksplikacji wybranych zagadnień. Kielce: Wyd. UJK.

Ir, E., Szkolak-Stępień, A. (2020). Wolontariat studencki kandydata na nauczyciela wczesnej edukacji. W: M. Muchacki, J. Machowska-Goc, B. Sufa (red.), Wolontariat w dobie plynnej rzeczywistości. Kraków: Petrus, s. 85-93.

Jaronowska, S. (2017). Przestanki i uwarunkowania wolontariatu w Polsce. W: E.M. Kulsza, B. Kosewska (red.), Wolontariat studencki krajowy i zagraniczny. Warszawa: Wyd. APS, s. 9-20.

Jordan, P., Ochman, M. (1997). Wolontariusze — źródtem sity organizacji. Baltimore: John Hopkins University.

Jurczak, E. (2011). Wolontariat w Polsce. Analiza socjologiczna działalności ochotniczej. [Praca doktorska. Kraków: UJ]. https://ruj.uj.edu.pl/xmlui/bitstream/handle/item/52267/jurczak_wolontariat_w_polsce_analiza_socjologiczna_2011.pdf?sequence $=1$ \&isAllowed $=\mathrm{y}($ dostęp $30 \mathrm{X}$ 2021).

Kanios, A. (2010). Społeczne kompetencje studentów do pracy w wolontariacie. Lublin: Wyd. UMCS.

Kromolicka, B. (2000). Wolontariusz w stuzbie cztowiekowi umierającemu. Na przykładzie Szczecińskiego Hospicjum Domowego. Szczecin: Wyd. USz.

Matuszewska, A. (2010). Wolontariat międzynarodowy jako forma aktywności edukacyjnej młodzieży. Olsztyn: Centrum Badań Europy Wschodniej.

Michaluk, M. (2013). Teoretyczne aspekty wolontariatu. W: M. Kołodziejski (red.), Wolontariat jako narzędzie do aktywnej integracji osób chorujących psychicznie. Łódź: Stowarzyszenie Młodzieży i Osób z Problemami Psychicznymi, Ich Rodzin i Przyjaciół „Pomost”, s. 11-59, bibliotekawolontariatu.pl/wp-content/uploads/to dziala.pdf (dostęp $30 \mathrm{X}$ 2021).

Muchacki, M. (2020). Wolontariat jak̄o e-środowisko stwarzające warunki wsparcia spotecznego. W: M. Muchacki, J. Machowska-Goc, B. Sufa (red.), Wolontariat w dobie plynnej rzeczywistości. Kraków: Petrus, s. 75-84.

Roguska, A.(2010). Wolontariat - działania na rzecz jednostki i spoteczeństwa. W: M. Danielak-Chomać, B. Dobrowolska, A. Rogulska (red.), Wolontariat w teorii i praktyce. Siedlce: Fundacja na Rzecz Dzieci i Młodzieży „Szansa”, s. 27-48. 
Targowska, M. (2017). Wolontariat jako droga kształtowania pasji i nabywania kompetencji zawodowych. W: E. M. Kulsza, B. Kosewska (red.), Wolontariat studencki krajowy i zagraniczny. Warszawa: Wyd. APS, s. 33-46.

http://bibliotekawolontariatu.pl/wp-content/uploads/vademecum_wolontariusza.pdf http://fundacja-umbrella.org.pl/portfolios/improve-impact-of-volunteering-on-personal-and-professional-growth/ (dostęp 20XI 2021).

http://isap.sejm.gov.p 1/DetailsServlet?id=WDU20160000239 (dostęp 30 III 2019).

https://www.cbos.pl/SPISKOM.POL/2020/K_037_20.PDF (dostęp 30 X 2021). 